\title{
妏腸管遺残の合併症
}

和歌山県立医科大学 消化器外科（主任：勝見正治教授）

$\begin{array}{llllllllllll}\text { 竹 } & \text { 井 } & \text { 信 } & \text { 夫 } & \text { 勝 } & \text { 見 } & \text { 正 } & \text { 治 } & \text { 青 } & \text { 木 } & \text { 洋 } & \text { 三 } \\ \text { 谷 } & \text { 口 } & \text { 勝 } & \text { 俊 } & \text { 柿 } & \text { 原 } & \text { 美千秋 } & \text { 嶋 } & \text { 田 } & \text { 浩 } & \text { 介 } \\ \text { 康 } & & \text { 権 } & \text { 三 } & \text { 湯 } & \text { 川 } & \text { 裕 } & \text { 史 } & \text { 坂 } & \text { 口 } & \text { 雅 } & \text { 宏 } \\ \text { 杉 } & \text { 本 } & \text { 恵 } & \text { 洋 } & \text { 児 } & \text { 玉 } & \text { 说 } & \text { 男 } & \text { 稲 } & \text { 生 } & \text { 誠 } & \text { 樹 }\end{array}$

\section{COMPLICATIONS DUE TO OMPHALOMESENTERIC DUCT AND MECKEL'S DIVERTICULUM}

Nobuo TAKEI, Masaharu KATSUMI, Yozo AOKI, Katsutoshi TANIGUCHI, Michiaki KAKIHARA, Kosuke SHIMADA, Kenzo KOH

Hiroshi YUKAWA, Masahiro SAKAGUCHI, Yoshihiro SUGIMTOTO, Etsuo KODAMA and Seiki INABU

Department of Gastroenterological Surgery, Wakayama Medical College, Wakayama

(Director : Prof. Masaharu KATSUMI)

脐晹管遺残は，長い間無症状に経過する例が多い。臨床的に問題になるのは，腸閉塞， 出血, 㮩室炎，穿孔などの合併症をきたした場合で，外科的治療が必要となる.

著者らは，1974年より1982年までの 9 年間に䐗腸管遺残10例を経験したので，その概 要を述べ, 若干の文献的考察を加えた。

新生児は 2 例で，最年長は 14 葴男子であった。性別では，男児 7 例，女児 3 例で，男 女比は2.3：1であった。術中偶然，発見されたのは1例で，他は脐腸管遺残の合併症 のため来院している，病型は，ィッケル秝室 7 例, 睹腸瘦 2 例, 索状物 1 例で, 合併症 の内訳は, 出血 3 例, 腸内容の排出 2 例, 腸重積 2 例, 腸閉塞 1 例, 炎症 1 例であった。

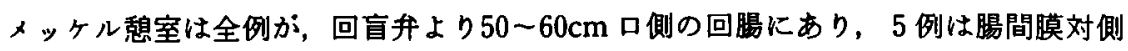
に, 2 例は腸間膜側に開口していた．異所性組織の迷入は胃粘膜が 5 例，羘組織が 1 例 にみられた。手術々式は，腸瘦切除術 2 例, 揳状切除術 3 例, 回腸切除術 5 例が行われ, 死亡は 1 例であった。

合併症の多くは，早急に外科的処置を必要とするため, 術前に診断を確定することは きわめて難しい，2歳以下の乳児の原因不明の腹痛，下血では，本症の可能性を考虑す べきことを強調したい.

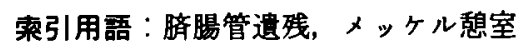

\section{I.はじめに}

腤腸管遺残は，剖検例の約 $2 \%$ みられ，その大部 分の症例は長い間無症状に経過する.しかし，その一 部は, 腸閉塞, 出血, 㮩室炎, 穿孔などの合併症をき たし，外科的治療が必要となることも多い，発症の時 期は多くは小児期にみられ,なかです 2 歳以下が約半
数であり，新生児期にもみられるので注意を要する。 䏽腸管 (omphalomesenteric duct or vitelline duct) は卵黄变と胎児腸管を連絡しており，胎生 5 週頃まで には，次第に閉鎖し吸収される。この脐腸管が閉鎖， 消失せずに残ったたすのが，䐗腸管遺残であり，Gray ら゙は图1に示すよらに, 脐腸管瘻 (patent om- 


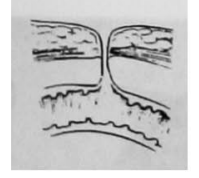

a. 胵腸管瘒
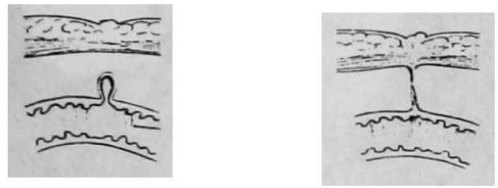

c.メッケル憩室

d. 索状物

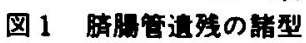

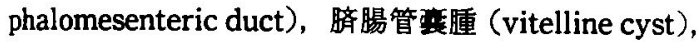
メッケル蒩室 (Meckel's diverticulum)，腈と腸管を 結ら゙索状物 (omphalomesenteric band)などの異常を 生じると述へている。

著者らは，過去 9 年間に脐晹管倳残10例を経験した のでその概要を述べるとともに，若干の文献的考察 を加兑，報告する。

\section{II. 自医例の概要}

1974年より1982年まで，和歌山県立医大消化器外科 で経稌した胳腸管遗残は表 1 亿示すと扣り10例であ る。新生児は 2 例で，最年長は出血を主訴として来院 した14葴の男子であった。10例中 4 例は 2 葴以下で, 初発症状の時期からみると，6例が 2 葴以下であった。 男女比は2.3：1であった。自鈳例10例のらち，術中に 偶然発見されたのは 1 例で，他は腈腸管遭践の合併症 のため来院している，病型はメッケル慗室 7 例，腈腸
瘦 2 例, 索状物 1 例で, 合併症の内訳は, 出血 3 例, 腸内容の排出 2 例, 腸重積 2 例, 腸閉塞 1 例, 炎症 1 例であった。

以下，脐腸管遗残の病型とその合併症について述べ る.

\section{1. 䐗脚管案}

症例 1 は生後すぐより, 脐部外飞 $\mathrm{T}$ 字型腸管脱出が みられ，当科へ紹介された，脐腸管完全瘦と考学られ た（写真 1 )。瘦孔造影で，膀腸管瘦であることが確め られ，数急手術が行われた. 回盲弁より $20 \mathrm{~cm}$ 口側の回 腸の腸間膜側と脐との間に $3 \mathrm{~cm}$ の刘腸管の完全な開 存を認め, 胳腸管瘦の切除が行われた。症例 2 は生下 時体重1,250g の未熟児で，脐からの粘液排出で気付か れ，生後 3 日目に当科へ紹介された，䐗腸管の開存が みられ，同部を切除した。しかし，術後30日目に瘾着 性イレウスを併発し再開腹した。吻合部の広範な瘁着 によるイレゥスで，口側腸管は著明に拡張し，S 状結腸 とも庶着していた，約 $40 \mathrm{~cm} の$ 腸切除を行ったが, 翌 日，呼吸循瓄不全のため死亡した。

\section{2. 来状物}

症例 3 は 6 歳男児で, 約 9 力月前と 4 力月前に突然, 脐部痛と呕吐を訴え，某医を受診した。発熱や下血は なく、腹部 X 線像では腸閉塞像を呈していた. しかし, 翌日には症状は全く消失し, 診断がつかないまま放置 していた，今回も同様の主訴で来院し，腹部 X 線像で 下部小腸の閉塞が疑われ(写真2). 腸重積を筑い注腸 造影を行った(写真了). 注腸造影では, 上行結腸は正 中に偏位し, 回腸末端より口側は造影されないため, 回腸の腸重積を疑い救急手術を行った。開腹すると, 回盲弁より $50 \mathrm{~cm}$ 口側の腸間膜対側に, 直经 $3 \mathrm{~cm}$ 長さ

表 1 䐗腸管の进残

\begin{tabular}{|c|c|c|c|c|c|c|c|c|c|c|}
\hline No. & 年命 & 性 & 病 型 & 合併症 & ${ }^{99 m} \mathrm{~T} c-\mathrm{P}$ & Ba透视 & 術 式 & 部位 & 所保 & 忶师 \\
\hline 1 & $4 h$ & $\mathbf{M}$ & 胳晹 案 & 腸管脱出 & l & I & 腸㜔切除 & 反対溉 & - & 硉 \\
\hline 2 & 3d & M & $"$ & 分泌渇出 & ノ & l & $"$ & $"$ & - & 死 \\
\hline 3 & $6 y$ & $M$ & 索状物 & 腸 閉 塞 & 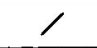 & $(-)$ & 搷状切除 & $"$ & - & 健 \\
\hline 4 & $10 \mathrm{~m}$ & F & メッケル腎宝 & 资 症 & $(+)$ & $(-)$ & 腸 切除 & 腸間膜 & 雸 & $"$ \\
\hline 5 & $1 y$ & F & $"$ & 腸重䔉 & ノ & $(-)$ & $"$ & 反対側 & - & $"$ \\
\hline 6 & $3 y$ & $M$ & $"$ & 血 & $(-)$ & $(-)$ & $m$ & 晹間膜 & 亗 & $"$ \\
\hline 7 & $4 y$ & $\mathbf{M}$ & $"$ & 腸 重 䖽 & I & 1 & $"$ & 反対傊 & 脺 & $"$ \\
\hline 8 & $7 y$ & $\mathrm{M}$ & $"$ & （術中） & Y & ノ & 偨状切除 & $"$ & 胃 & $"$ \\
\hline 9 & $13 y$ & F & $"$ & 血 & $(-)$ & $(+)$ & $"$ & $"$ & $"$ & $"$ \\
\hline 10 & $14 y$ & $\mathbf{M}$ & " & 血 & $(+)$ & $(-)$ & 晹切除 & $"$ & " & $"$ \\
\hline
\end{tabular}




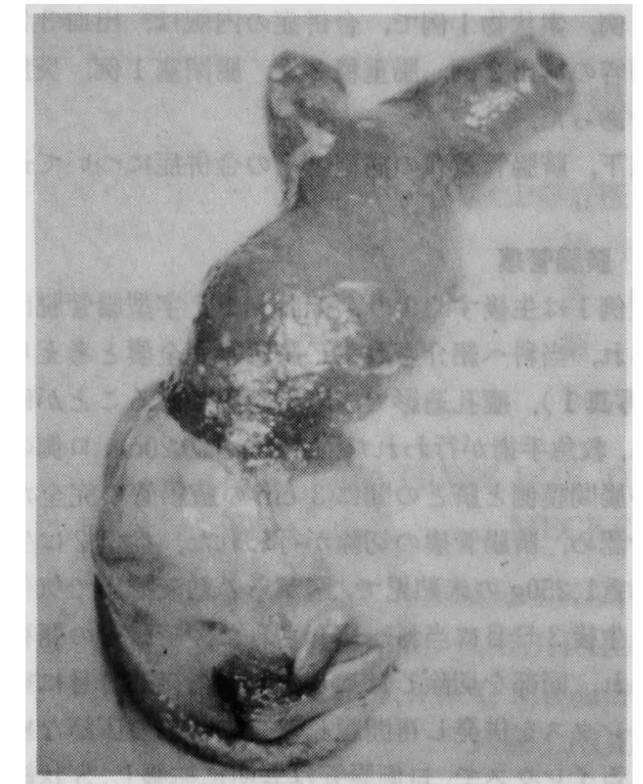

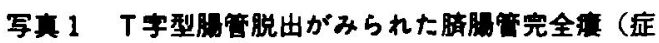
例 1).

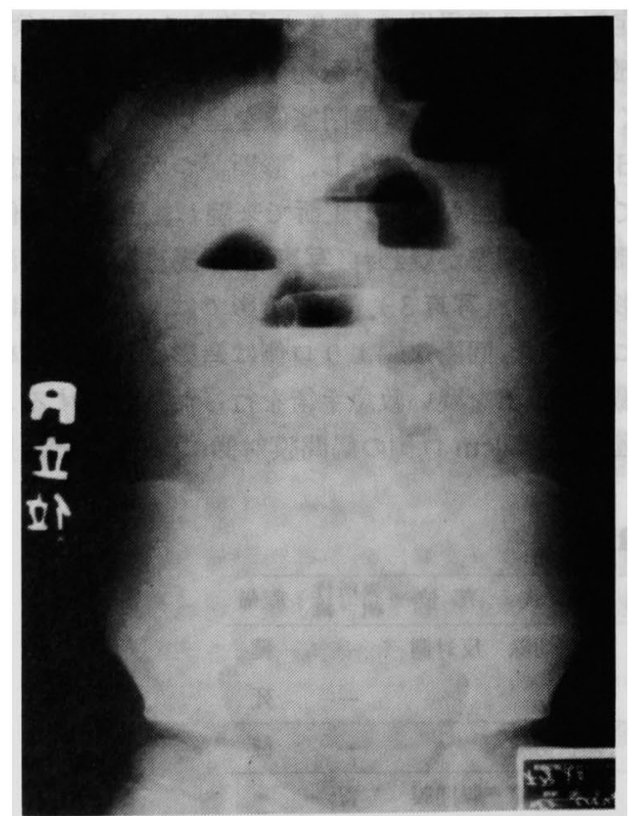

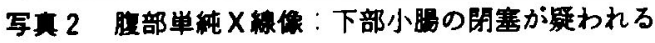
(症例 3 ).

$2.5 \mathrm{~cm}$ のメッケル賏室が存在し, 悡室の先端は脐と比 較的太い索状物で連絡し，この間に腸係镑が陥入し， 絞拒性イレウスをおこしていた。索状物を含めメッケ ル賏室を妡除した。

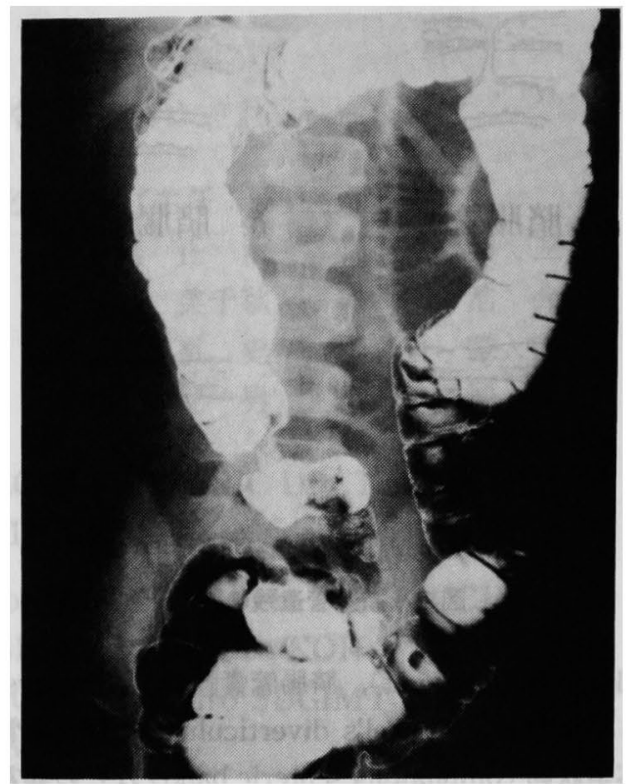

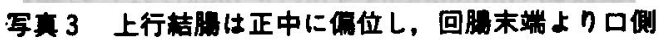
は造影されていない（症例 3 ）。

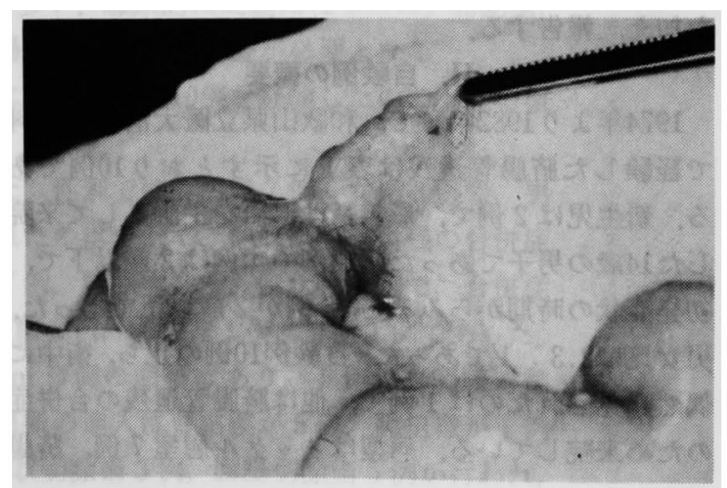

写真 4 mesodiverticular vascular bandがみられ 3 (症例 6 ).

3. メッケル䚋室

メッケル賏室には, 前述したよらにその先端に遺残 索状物をるつるのと、これを欠くものとがあり，頻度 は後者がはるかに多い，症例 6 は, 胎生期に卵黄腸管 の血行である vitelline artery の遺残物で, 顋室の先端 から腸間膜基底部まで走る索状物 (mesodiverticular vascular band）を認めた（写真 4)。部位は全例が回 盲弁より50 60 cm 口側の回腸にみられ，5例は腸間 膜対側に，2 例（症例 4，6）は組織学的検討により， 腸間膜側に存在する䕀室と診断できた。

合併症をみると、メッケル慜室が内翻し, 腸重積の 


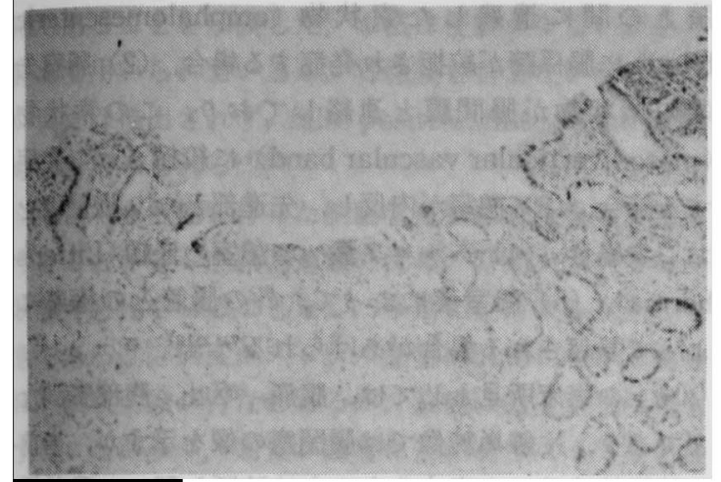

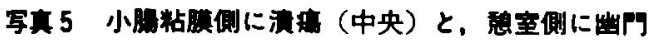

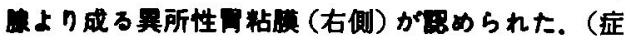
列10)

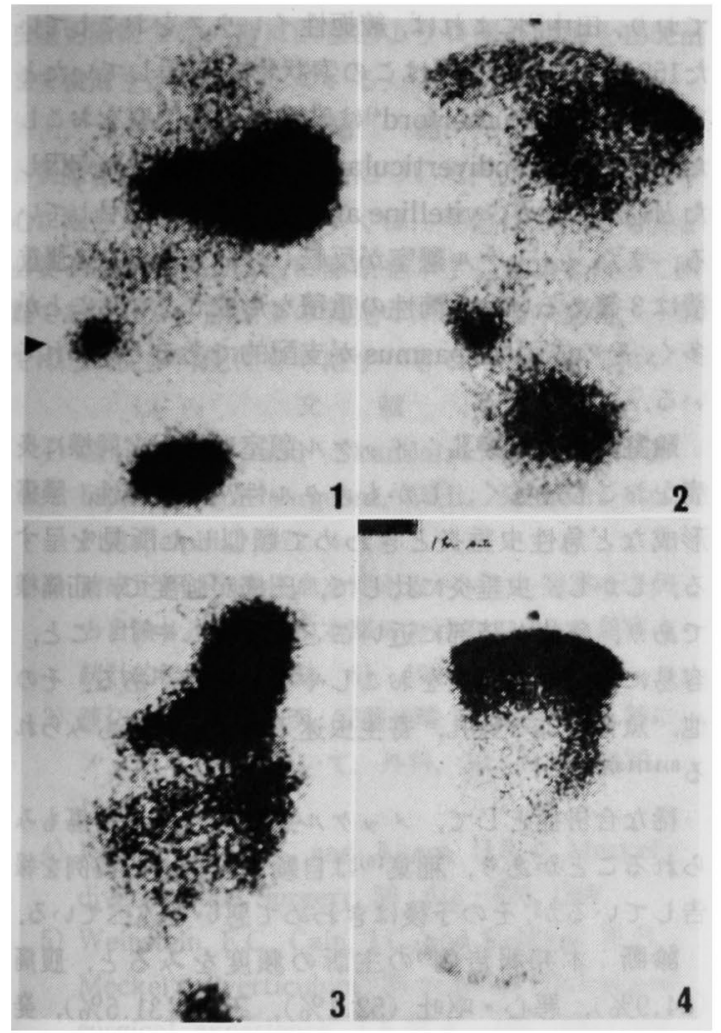

写竞 $6{ }^{99 m}$ Tc pertechnetate scanning

$1:$ 症例 $4,2:$ 症例 $10,3:$ 症例 $6,3:$ 症例 9.

leading point となったるのが 2 例にみられ, 出血が 3

例，頽室炎が 1 例にみられている.

また, ッッル憩室には60\%の頻度で，異所性組織 の迷入があるといわれ，自験例 5 例に胃粘膜の迷入が,

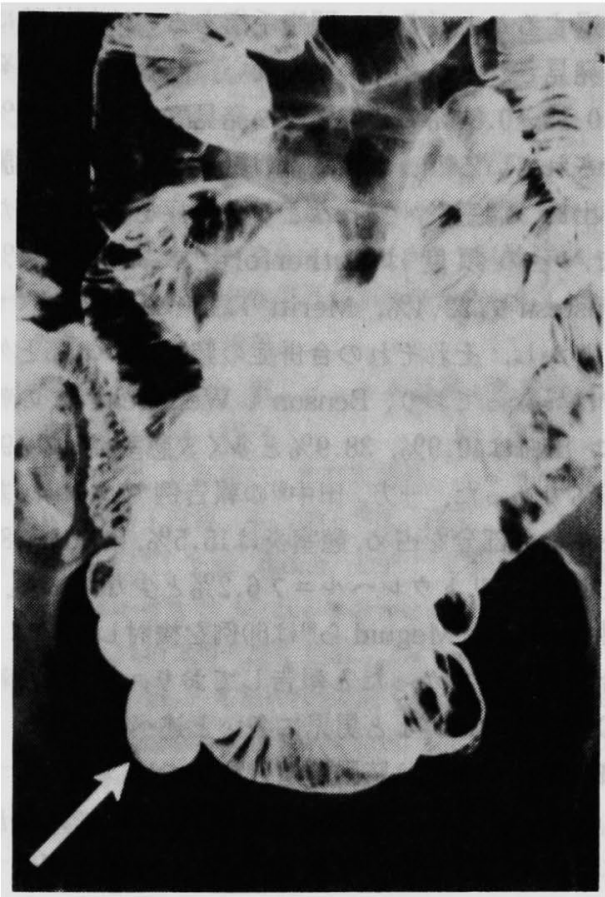

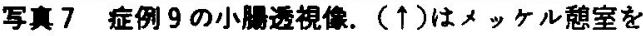
示す.

1 例に䐙組織の迷入がみられた。症例 6，9，10では 溃晹形成がみられ，この部位からの出血が主訴となっ たと考えられた（写其 5 ）.

診断は一般的には困難である。しかし，胃粘膜の 迷入が多いことから, ${ }^{99 m}$ Tc-pertechnetate scanning ( ${ }^{90 \mathrm{~m}}$ Tc-P) によって診断可能であり，自験例でも症例 4，10では，胃と膀肤以外の腹部中央に小さな円形の 取り迈みがみられ，術前に診断できた。しかし，症例 6，9ではメッケル憩室は描出されず，その5ちの1 例は, 組織学的に胃粘膜の迷入が証明されなかった（写 +1 6 ).

また，出血例では上部消化管透視，小腸透視，注腸 透視が消化性溃痬，腸重積との鑑別において重要であ ク，6例に施行されたが，わずかに 1 例のみ診断でき た（军其７）。自験例では乳児期より間歇的な大量の下 血によって，時にはショック状態を呈し，緊急輸血を 必要とした例が 2 例あり，診断に難涉した。

治㞠法は 2 例に腸度切除除術， 3 例に桠状切除訹， 5 例に回腸切除術を行った。 自験例中 1 例の死亡例が あるが，他の例はいずれる全治退院した。

\section{III. 考 察}

脐腸管遺残による異常，特にメッケル嚊室は無症状 
に経過することが多く，開腹手術あるいは剖検時に偶 然に発見されることが少なくない，開腹手術時の発見 率は $0.13-0.84 \%$ で，剖検時の発見率は $1.3-2.0 \%$ と 報告されている2)3)。臨床的には問題になるのは，腸閉 塞, 出血, 慗室炎, 穿孔などの合併症を生じてきた場 合でその頻度はRutherford"によよれば54\%， Weinstesn ${ }^{51}$ は22.4\%, Meritt ${ }^{6 /}$ は15一25\%之述べてい る。しかし，それぞれの合併症の頻度は，本邦と外国 とでは異なっており, Benson ${ }^{7)}$, Weinstein ら5の報告 では，出血は $40.9 \% ， 38.9 \%$ と多く，想室炎は $20.9 \%$, 17.9\%であった，一方，田中》の報告例では，腸閉塞が $53.8 \%$ と大部分を占め, 㮩室炎は $15.5 \%$, 出血は $6.8 \%$, 穿孔6.2\%，リトゥレールニア6.2\%と少なかった。

男女比では, Meguid らは60例を検討し，3.6:1の 割合で男児に多かったと報告しており，田中蕔告 例407例では2.3：1 と男児に多いと述へている。

腤得店：この型は脐腸管遗残の中では，きわめて稀 で, Benson")によれば115例中 7 例(6.1\%)で，長島 ${ }^{101}$ によると1970年までの本邦報告例はわずか15例にすぎ ないと報告している，又，男女比では男児に多くみら れるとの報告が多い，本症は出生時より，脐部からの 分泌物，腸管の脱転によって気付かれる、Gray ${ }^{5}$ によれ ぱ回腸粘膜の脱出は脐腸管㿉の $20 \%$ している。

出血（メッケル秝室）：乳幼児の合併症として最も普 通に認められ，特に 2 歳以下では，突然下血をきたし， しかも多量で，時にはショック状態となることもある。 しかし，長期間にわたり，間歇的に出血する場合すあ る. 便の性状は出血量によってタール状から，群血色 まで種々であるが，暗赤色のことが多く，粘液の混入 がみられないのが特徵である。

出血の合併か，外国例に多い理由として，異所性組 織，特に胃粘膜迷入の頻度が高いことがあげられる。 Benson $^{7}$ によれば， 53.4\%に異所性組織の迷入がみら れ，そのうち95\%は胃であったとの報告に比へ，本邦 では異所性組織の迷入はわずか $11.7 \%$ オりり，その5 ち胃粘膜は $52 \%$ が存在したのみであったと述べられて

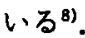

出血の原因は迷入した胃粘膜のほとんどが胃底腺を含 み，塩酸とペブシンが分泌され，抵抗の少ない回腸粘 膜に消化性潰瘍が形成されるためであり，この潰瘍の 多くは，䕀室の䅡部に発生し，胃粘膜の面積か $1.2 \mathrm{~cm}^{2}$ 以上で発生するといわれている゙11.

䭪閉塞：比較的多発するか，その原因は（1）秝室と
脚との間に遗残した索状物 (omphalomesenteric band）に腸保蹄が皎扼され発症する場合，（2）唕室先 端の索状物が腸間膜と連絡しており，この索状物 （mesodiverticular vascular band）に皎扼されて発症 する場合，（3）㮩室が内反し，先進部となり腸重皘を

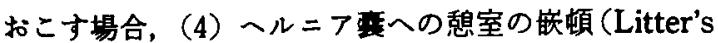
hernia)，(5)䄭室炏に上って，外の腸管との麻着に よって惹起される場合があげられる゙1213).

以上の臨床所見としては, 腹痛, 呕吐, 腹部膨満な ぞであり，X 線単純像では腸閉塞の像を示すが，行前 に妏腸管遗残に由来するすのとは診断し難い，乳幼児 に拀いて，突然腸閉塞をきたし揚合には，本症を念頭 に置く必要があろう。

Kühne ${ }^{14)}$ は10\%に omphalomesenteric band を認め

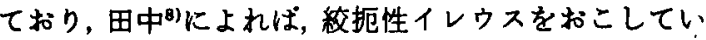
た152例のちち66.7\%はこの索状物に起因していたと 透べている. Rutherford"は乳幼児で腸閉塞をおこし た半数が, mesodiverticular vascular band $に$ 起因し たと述べており，vitelline arteryの遺残に注目してい る. またメッケル㮩室が反転し，先進部となる腸重 積は 3 简あるいは 5 筒性の重皘を形成していることが 多く，その成因は spasmus が支配的であるといわれて いる.

㮩室炎およU穿孔：メッケル頽室は虫垂と同様に炎 症をおこしやすく，しかすカタル性，蜂骷織性，膿場 形成など急性虫垂炎ときわめて類似した所見を呈す る。しかし，虫垂炎に比して，代痛が強度で，疝痛様 であり，部位が脐部に近いこと，穿孔しやすいこと， 容易に汎発性腹膜炎をおこしやすい特徵がある，その 他，魚骨に上る穿孔，寄生䗇入による炎症もみられ $3^{8) 1112 \text { ) }}$.

稀な合併症として、メッヶル䄸室癌などの腫瘍むみ られることがあり，稲葉 ${ }^{(5)}$ は自験例を含めて17例を報 告しているが，その予後はきわめて悪いと述へている.

診断：本邦報告(例查の主訴の頻度をみると，腹痛 $(84.9 \%)$, 覀心・呕吐 $(52.1 \%)$, 下血 $(31.5 \%)$, 発

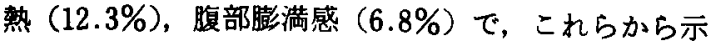
唆される疾患は，腸閉塞，消化性潰湯，虫垂炎など多 皮にわたる．術前に確実にメッケル稳室と診断される ことは少なく，早急に開腹術をしなければならないこ ともあって，詠断は困難である。

1912年 Harper $5^{16)} に よ り ，$ technetium が胃粘膜に 選択的に集積することを発表して以来, Irvine ${ }^{17)}$ Jewett ら ${ }^{(8)}$ は, 異所性胃粘膜を有する本症の診断に有 
用でることを示唆した，本法は侵熟が少ない点から 好んで用いられているが，胃粘膜を含まない例や少な い例では描出されず， false positive, false negative 例 の報告るみられる

治康：合併症を伴った膀腸管遗残は急性腹症で発症 †ることが多く，原因追求のため，時間をついゃし， 状臨を熏化させることなく，早期に手術にふるきるへ きであろ5．病変がメッケル憩室に限局している場合

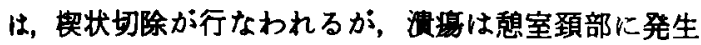
ナることが多く，病変が腸管に及ぶ場合には憩室を含 めて器切除することが望むしい。

他の目的で開腹され，偶然に発見された無症状の彭 室でも，全身状態の許すかぎり，できるだけ切除すべ きであり，著者らは，日常の臨床において症例の多い 虫垂切除術では，特に回盲部より口侧の回腸を $150 \mathrm{~cm}$ まで釦策することにしている。

\section{IV. 桔 語}

胳渴管遗残による合併症について，自駼例10例を中 心に報告した，合併症の多くは，早急に外科的処置を 必要とするため，術前に診断を下すことはきわめて困

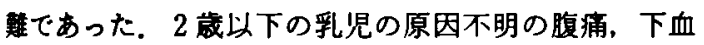
では，本症の可能性を考虑すべさとを強調したい。

\section{文献}

1) Gray S.W. and Skandalakis, J.E. : Embryology for surgeons, W.B. Saunders Co., Philadelphia, 1972.

2）洼成正智：畉巣出血を伴えるィッケル想室の 1 例 と自领 4 例を含めて本邦におけるメッケル想室の 統計的観察。日消誌，61：199-204，1964.

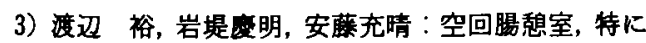
メッケル意室について。外科, $30: 1135-1139$, 1968.

4) Rutherford, R.B. and Akers, D.R.: Meckel's diverticulum. Surgery, $59: 618-626,1966$.

5) Weinstein, E.C., Cain, J.C. and ReMine, W.H. : Meckel's diverticulum : 35 years of clinical and surgical experience. J.A.M.A., 182: 251-253, 1962.

6) Meritt, W.H. and Rabe, M.A. : Meckel's diverticulum : Review of the literature and report of an unusual case. Arch. Surg., 113: 1083-1095, 1950.

7) Benson, C.D. : Surgical implication of Meckel' s diverticulum : Pediatric surgery, p. 955, Year Book Medical Publishers, London, 1979.
8) 田中早苗, 折田菜三, 国米欣明他: Meckel 憩室 一本邦報告例444例の統計的橎察を中心に一。外科 診療, $13 ： 818-825,1971$.

9) Meguid, M., Canty, T. and Eraklis, A.J. : Complications of Meckel's diverticulum in infants. Surg. Gynec. \& Obstet., 139 : 541-544, 1974.

10）長島金二：四説新生児外科診寮指針. p. 214，金原 出版社，東京，1976。

11）岩 喬，宮下微：メッケル想室. 外科診療, $16: 255-262,1974$.

12）高橋良吉, 日高靖二, 加部吉男他：メッケル秝室. 小児外科・内科， $8: 753-758 ， 1976$.

13) Root, G.T. and Baker, C.P.: Complications associated with Meckel's diverticulum. Amer. J. Surg., 114 : 285-288, 1967.

14) Kühne, H.: Chirurgische Komplikationen beim Meckelschen Divertikel. zb. Chir., 83: 17 $-27,1958$.

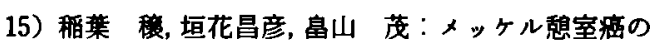
1 例。外科診寮， $1: 87-93 ， 1959$.

16) Harper, P.V., Anderson, G., Lathrop, K.A., et al.: Technetium-99, as a biological tracer (Abstr.). J. Nucl. Med., $3:$ 209, 1962.

17) Irvine, W.J., Stewart, A.G., Mcloughlein, G.P., et al.: Appraisal of application of ${ }^{90 \mathrm{~m}} \mathrm{Tc}$ in the assessment of gastric function. Lancet, $23: 648$ $-653,1967$.

18) Jewett, T.C., Duszynski, D.O. and Allen, J.E. : The visualization of Meckel's diverticulum with ${ }^{99 m}$ Tc-pertechnetate. Surgery, 68: 567 $-570,1970$.

19）勝部宥二，塩崎 梓，浦 伸三他：街前に診断しえ た Meckel 秝室の 1 例。和歌山医学, $24: 33-41$, 1973.

20）平石 聘，志田博司，三浦寿男男：腹部"9om TcNa-Pertechnetate Scanningにより診断を確定し 得た Meckel 㮩室の 2 例. 日少誌, $80 ： 187-193$, 1976.

21) Smith, F.R., Rheingold, O.J., Kanner, R., et al.: Meckel's diverticulum. Am. J. Surg., 72: 655 $-659,1979$.

22）鉿木宏志，西城英郎，坂倉 究他：傽管遭残によ るイレゥス，小児外科，12：479-484，1980。

23）矢野博道，松本英則，龍 忠彦他：卵黄晹管遺残21 例の検討。小児外科，11：233-240，1979. 